\title{
The efficiency of energy and protein utilization by growing pigs fed diets containing both full-fat rape seeds and rapeseed meal
}

\section{Stanisława Raj, Maria Kotarbińska, H. Fandrejewski and Katarzyna Chabiera}

\author{
The Kielanowski Institute of Animal Physiology and Nutrition, \\ Polish Academy of Sciences \\ 05-110 Jablonna, Poland
}

(Received 9 March 1995; accepted 28 April 1995)

\begin{abstract}
Twenty-four Polish Landrace pigs (12 gilts and 12 barrows) fattened from 30 to $95 \mathrm{~kg}$ body weight were fed diets containing 18\% rapeseed meal (RSM) and full-fat rape seeds (RS) in the following amounts: 0 (group RS-0), 10 (group RS-10) or $20 \%$ (group RS-20). The pigs were fed on an individual basis with rations having equal energy, protein and lysine contents. Nitrogen balance was determined at 40,60 and $80 \mathrm{~kg}$ liveweight. Metabolizable energy and protein utilization were determined by the slaughter technique. The thyroid gland, liver and kidneys were weighed and plasma $T_{3}$ and $T_{4}$ levels assayed.

Nitrogen retention was on average 12 and $17 \%$ lower $(\mathrm{P}<0.01)$ in groups RS- 10 and RS-20 than in RS-0; the negative effect of rape seeds on nitrogen utilization intensified as fattening progressed. Metabolizable energy utilization in pigs receiving $20 \%$ RS was 2.5 and $3.4 \%$ worse $(\mathrm{P}<0.05)$ than in groups RS-10 and RS-0, respectively.

As glucosinolates intake increased, the weight of the internal organs rose and $T_{3}$ and $T_{4}$ levels declined. These changes were not, however, proportional to the amount of glucosinolates intake.

The combined use of RSM and RS in the diets of growing pigs had an unfavourable effect on protein and energy utilization.
\end{abstract}

KEY WORDS: pig, nitrogen retention, energy metabolism, glucosinolate, internal organs, thyroid

\section{INTRODUCTION}

Rapeseed oilmeal (RSM) is a valuable source of protein, but $1 \mathrm{~kg}$ dry matter (DM) of this meal contains only 12 MJ ME (Raj et al., 1990), i.e. almost 2 MJ less 
than soyabean oilmeal. This limits its use in the feeding of growing pigs, which require high energy feeds (Campbell and Taverner, 1986). Results comparable to those obtained using soyabean meal can be obtained with diets containing high levels of RSM (over 15-20\%), supplemented with a high energy component, e.g cereal starch or animal fat (Chabiera et a., 1994; Fandrejewski et al., 1994; Thomke, 1984).

Full-fat raw rape seeds can also be used to increase the energy content of feeds for pigs (Gill et al., 1989; Glapś et al., 1992; Skomiał et al., 1993). The addition of rape seed to a feed raises its glucosinolate (GL) content and introduces an enzyme, myrosinase, which can adversely affect the physiology of animals. This was found in studies on rats (Bille et al., 1983b), among others.

The objective of this study was to determine the effect of feeding rapeseed meal plus rape seeds added to increase the energy content in the diet, on the fattening performance, especially energy utilization, and on body composition and internal organ weights in pigs.

\section{MATERIAL AND METHODS}

Rape seeds (RS) and rapeseed meal (RSM) were from the same batch of double low rape and contained 20.5 and $12.3 \mathrm{MJ} \mathrm{ME} / \mathrm{kg} \mathrm{DM}$, and 22.8 and 5.5 M glucosinolates per gram of fat-free dry matter, respectively (Raj et al., 1993). The experimental mixtures contained the same amount of rapeseed meal $(18 \%)$ and various amounts of rape seeds: 0 (group RS- 0 ), 10 (group RS-10) or $20 \%$ (RS-20) (Table 1) substituted for barley.

The concentration of metabolizable energy in mixtures RS-0, RS- 10 and RS-20 equaled $11.8,12.4$ and $13.0 \mathrm{MJ} / \mathrm{kg}$, respectively (Table 2 ). The mixtures were supplemented with synthetic lysine up to not less than $5.2 \%$ of crude protein. The ratio of crude protein and lysine to metabolizable energy was the same in all the diets and equalled 13.4 and $0.7 \mathrm{~g}$ per $1 \mathrm{MJ}$.

Twenty-four Polish Landrace pigs (12 gilts and 12 barrows) divided into 3 groups were fattened from 30 to $95 \mathrm{~kg}$ liveweight. The animals were kept in individual pens without bedding. Mean daily energy intake was similar in all groups (Table 2). Feed rations were increased weekly according to the weight of the animals. During the experiment, the barrows were periodically transferred to metabolic cages and after 3 days of adaptation, four-day faeces and urine collections were conducted at live weights of 40,60 and $80 \mathrm{~kg}$. Nitrogen digestibility and balance were determined.

At the end of fattening, the animals were slaughtered and the protein and fat contents of the empty body were determined, the thyroid, liver and kidneys weighed. The chemical composition of the feeds, faeces and body of the animals, 
TABLE 1

Composition of diets

\begin{tabular}{lccc}
\hline & & Diet & \\
\cline { 2 - 4 } & RS-0 & RS-10 & RS-20 \\
\hline \multicolumn{1}{c}{ Components, \% } & & 10 & 20 \\
Raw rape seeds (RS) & 0 & 18 & 18 \\
Rapeseed meal (RSM) & 18 & 69 & 59 \\
Barley & 79 & 0.19 & 0.13 \\
L-lysine.HCL & 0.24 & 0.71 & 0.75 \\
Dicalcium phosphate & 0.69 & 0.30 & 0.30 \\
Salt (NaCl) & 0.30 & 1.80 & 1.8 \\
Vitamin- mineral premix & 1.77 & & \\
$\quad$ Chemical composition & & 903 & 911 \\
Dry matter (DM), g/kg & 896 & & 190 \\
In DM, g: & & 184 & 108 \\
crude protein & 177 & 74 & 71 \\
ether extract & 28 & 69 & 20.3 \\
crude fibre & 66 & 18.9 & 3.55 \\
gross energy, $\mathrm{MJ} / \mathrm{kg}$ & 17.7 & 2.26 & \\
glucosinolate, $\mathrm{mM} / \mathrm{kg}$ & 0.95 & & \\
\hline
\end{tabular}

RS $-22.8, \mathrm{RSM}-5.57 \mu \mathrm{M} / \mathrm{g}$ fat-free dry matter

TABLE 2

Nutritive value of diets and daily intake

\section{Nutritive value}

Metabolizable energy, $\mathrm{MJ} / \mathrm{kg}$

11.8

12.4

13.0

Digestible protein, g/MJ ME

10.4

10.3

10.2

Lysine, g/MJ ME

0.70

0.70

0.70

Metionine + cystine, g/MJ ME

0.57

0.56

0.55

Threonine, g/MJ ME

0.43

0.50

Tryptophan, g/MJ ME

0.17

0.16

0.16

Daily intake

Feed, kg

Metabolizable energy, MJ

Digestible protein, $\mathrm{g}$ 299

Glucosinolate, $\mathrm{mM}$

2.1

RS, RSM - see Table 1 
as well as the nitrogen content of the urine were determined by conventional methods. Gross energy of feeds, faeces and urine were measured in a calorimetric bomb. ME was calculated as the difference between energy intake and excretion in urine and faeces. Regression equations formulated by Fandrejewski (1992) were used to estimate the initial protein and energy contents in the body of the experimental animals. Energy deposition was estimated according to protein and fat gain in the body, using the coefficients given by Brouwer (1965) for protein $(23.9 \mathrm{~kJ} / \mathrm{g})$ and fat $(39.8 \mathrm{~kJ} / \mathrm{g})$.

The glucosinolate (GL) contents in RS and RSM, expressed as the sum of the fractions, was determined by the Youngs-Wetter method, modified by Byczynska (1971). The amino acid composition of feeds was determined using a Beckman Unichrom analyzer as described by Buraczewska et al. (1987). Plasma thyroid hormones were assayed in blood sampled after slaughter using RIA kits (RIA-T 3 and RIA- T $_{4}$ from POLATOM).

The statistical significance of differences was evaluated by variance analysis taking into account effect of diet and sex, and for nitrogen balance, diet and body weight.

\section{RESULTS}

The apparent digestibility of crude protein (Table 3 ) averaged $77.7 \%$ and did not depend on the seed content in the diet, but was 3.8 and $2.9 \%$ lower $(\mathrm{P}<0.01)$ in pigs weighing $40 \mathrm{~kg}$ than in 60 or $80 \mathrm{~kg}$ animals, respectively. Nitrogen

TABLE 3

Nitrogen balance ( $\mathrm{g} / \mathrm{day}$ ) and $\mathrm{N}$ digestibility in growing pigs fed diets containing 0,10 or $20 \%$ of rape seeds $(n=4)$

\begin{tabular}{|c|c|c|c|c|c|c|c|}
\hline \multirow{2}{*}{ Item } & \multicolumn{3}{|c|}{ Diet } & \multicolumn{3}{|c|}{$\mathrm{N}$-retention at body weight } & \multirow{2}{*}{ sem } \\
\hline & RS-0 & RS- 10 & RS-20 & $40 \mathrm{~kg}$ & $60 \mathrm{~kg}$ & $80 \mathrm{~kg}$ & \\
\hline $\mathrm{N}$-intake & 64.2 & 63.4 & 63.3 & $55.4^{\wedge}$ & $63.9^{\mathrm{B}}$ & $71.6^{\mathrm{C}}$ & 0.143 \\
\hline $\mathrm{N}$-in faeces & 13.7 & 14.7 & 14.5 & $13.6^{\mathrm{A}}$ & $13.3^{\mathrm{A}}$ & $15.5^{\mathrm{B}}$ & 0.210 \\
\hline $\mathrm{N}$-in urine & $31.6^{a}$ & $32.8^{: \mathrm{hh}}$ & $33.2^{\mathrm{b}}$ & $24.4^{\wedge}$ & $33.7^{\mathrm{B}}$ & $39.3^{\circ}$ & 0.216 \\
\hline N-retained* & $18.9^{A}$ & $16.6^{\mathrm{Ba}}$ & $15.6^{\mathrm{Bh}}$ & 17.4 & 16.9 & 16.8 & 0.185 \\
\hline $\begin{array}{l}\text { Digestibility } \\
\text { of nitrogen, } \%\end{array}$ & 78.4 & 77.7 & 77.0 & $75.5^{\wedge}$ & $79.3^{\mathrm{R}}$ & $78.4^{\mathrm{K}}$ & 0.342 \\
\hline $\begin{array}{l}\mathrm{N} \text { retained as } \% \text { of } \\
\mathrm{N} \text { digested }\end{array}$ & $37.8^{\wedge}$ & $34.1^{\mathrm{AB}}$ & $32.8^{\mathrm{B}}$ & $41.5^{A}$ & $33.3^{\mathrm{B}}$ & $29.9^{c}$ & 0.319 \\
\hline
\end{tabular}

* - diet $\mathrm{x}$ balance interaction $(\mathrm{P}<0.05)$, details for the nitrogen retention see Figure 1

a, b, c $-\mathrm{P}<0.05 ; \mathrm{A}, \mathrm{B}, \mathrm{C}-\mathrm{P}<0.01$ 


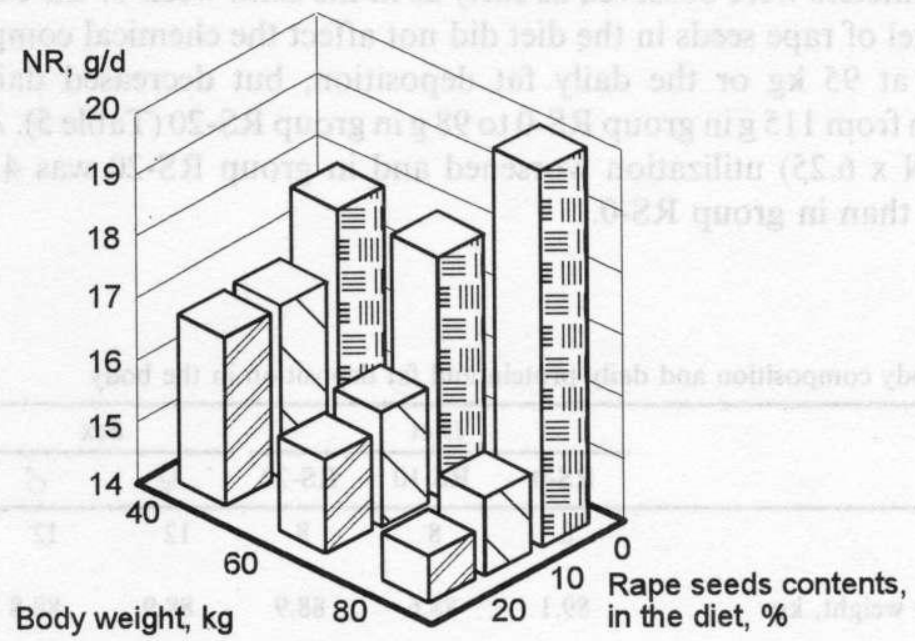

Figure 1. Diet $x$ body weight interaction for nitrogen retention $(\mathrm{RN})$. The treatment began from $30 \mathrm{~kg}$ liveweight

retention (NR) decreased as the proportion of seeds in the diets increased. A significant $(\mathrm{P}<0.05)$ interaction between diet and body weight was found; as the body weight increased, NR decreased in groups RS-10 and RS-20, and rose in group RS-0 (Figure 1). A similar direction of changes was observed in utilization of nitrogen absorbed in relation to nitrogen retained.

Despite the high level of feeding $\left(1.3 \mathrm{MJ} \mathrm{ME} / \mathrm{kg}^{0.75}\right)$ and the high proportion of rape seeds (up to $38 \%$ in group RS-20), the pigs ate the provided rations. The average daily weight gain decreased as the percentage of seeds in the feed rose (Table 4). A $20 \%$ seed content in the diet lowered the average daily weight gain by $88 \mathrm{~g}$ and deteriorated the use of $\mathrm{ME}$ to $5.5 \mathrm{MJ}$ per kilogram of body weight

TABLE 4

Performance of growing pigs

\begin{tabular}{|c|c|c|c|c|c|c|c|}
\hline \multirow{2}{*}{ Item } & \multirow{2}{*}{ 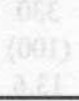 } & \multicolumn{3}{|c|}{ Diet } & \multicolumn{2}{|c|}{ Sex } & \multirow{2}{*}{ sem } \\
\hline & & RS-0 & RS-10 & RS-20 & 우 & 0 & \\
\hline No of pigs & & 8 & 8 & 8 & 12 & 12 & - \\
\hline Initial body weight, $\mathrm{kg}$ & 72.0 & 29.9 & 29.5 & 29.9 & 29.3 & 29.7 & 0.207 \\
\hline Final body weight, kg & & 94.2 & (1) 94.5 & 94.3 & 94.0 & 94.7 & 0.270 \\
\hline Average daily gain, $\mathrm{g}$ & & $739^{A}$ & $692^{\mathrm{AB}}$ & $651^{\mathrm{B}}$ & 696 & 692 & 15.770 \\
\hline $\mathrm{ME} /$ gain ratio, $\mathrm{MJ} / \mathrm{kg}$ & & $39.2^{\mathrm{A}}$ & $41.9^{\mathrm{AB}}$ & $44.7^{\mathrm{B}}$ & 41.7 & 42.3 & 0.843 \\
\hline
\end{tabular}

A, B, C - P $\leqslant 0.01$ 
gain $(\mathrm{P}<0.01)$. Significant differences among the groups of animals in respect to these parameters were observed as early as in the sixth week of the experiment.

The level of rape seeds in the diet did not affect the chemical composition of the body at $95 \mathrm{~kg}$ or the daily fat deposition, but decreased daily protein deposition from $115 \mathrm{~g}$ in group RS-0 to $98 \mathrm{~g}$ in group RS-20 (Table 5). As a result, protein $(\mathrm{N} \times 6.25)$ utilization worsened and in group RS-20 was $4.5 \%$ lower $(\mathrm{P}<0.05)$ than in group RS-0.

TABLE 5

Chemical body composition and daily protein and fat deposition in the body

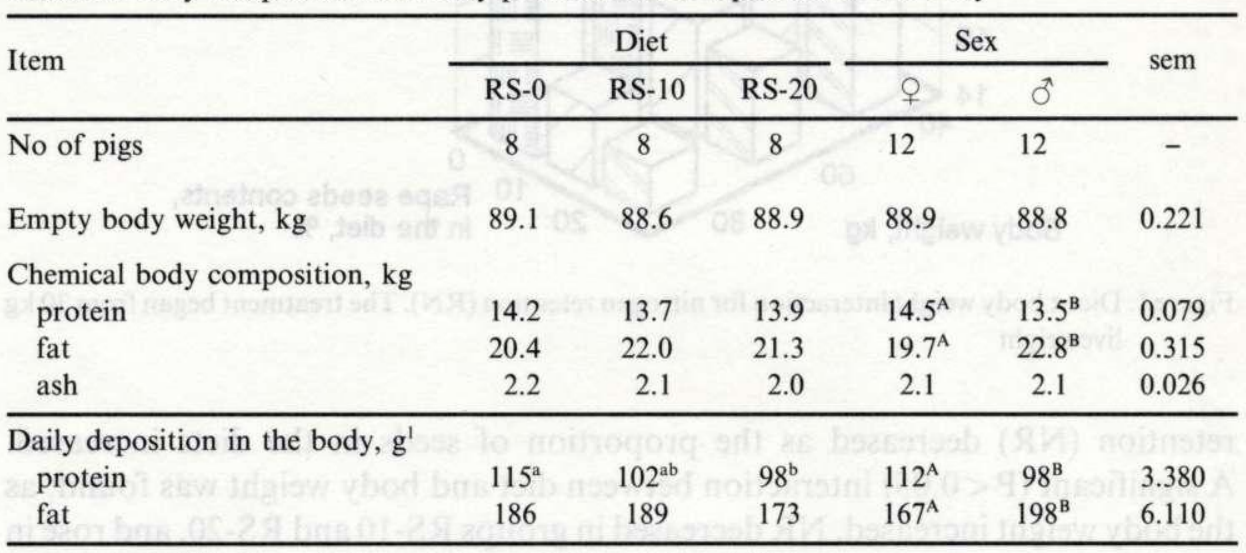

${ }^{1}$ content at $30 \mathrm{~kg}$ liveweight: protein $=4.25 \mathrm{~kg}$; fat $=4.17 \mathrm{~kg}$

a, b $-\mathrm{P}<0.05 ; \mathrm{A}, \mathrm{B}, \mathrm{C}-\mathrm{P}<0.01$

TABLE 6

Size of internal organs and thyroid hormones level in serum

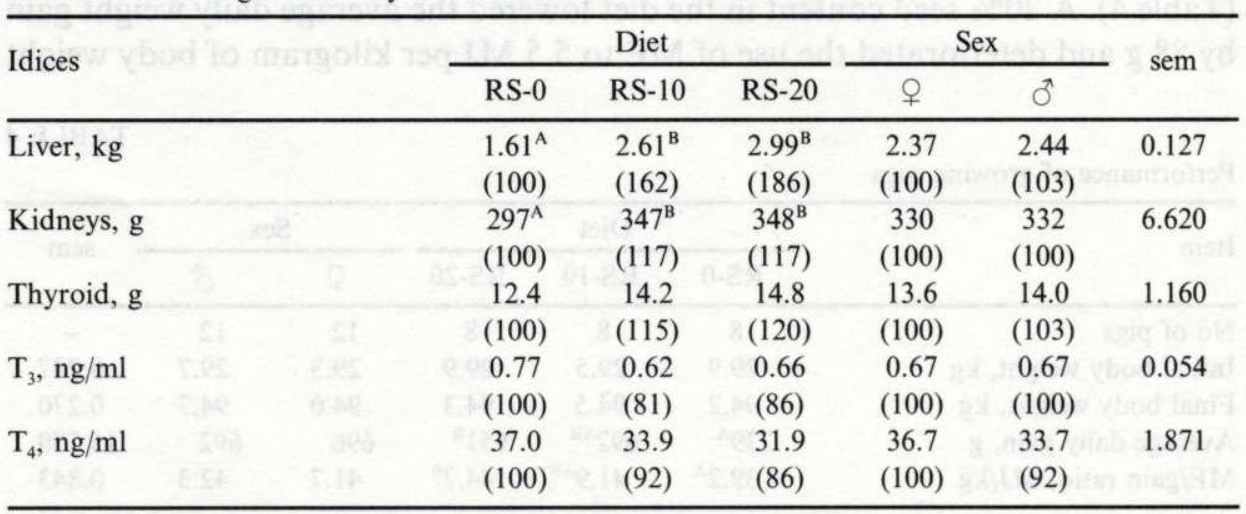

$\mathrm{A}, \mathrm{B}-\mathrm{P}<0.01$ 
TABLE 7

Energy balance in growing pigs fed diets containing 0,10 or $20 \%$ rape seeds

\begin{tabular}{|c|c|c|c|c|c|c|}
\hline \multirow{2}{*}{ Item } & \multicolumn{3}{|c|}{ Diet } & \multicolumn{2}{|c|}{ Sex } & \multirow{2}{*}{ sem } \\
\hline & RS-0 & RS-10 & RS-20 & 우 & $\sigma^{\pi}$ & \\
\hline No of pigs & 8 & 8 & 8 & 12 & 12 & - \\
\hline 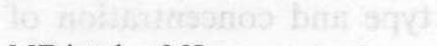 & & & & & & \\
\hline ME intake, MJ & 28.9 & 29.0 & 29.2 & 28.8 & 29.1 & 0.311 \\
\hline Energy retained as protein, $\mathrm{MJ}$ & $2.7^{\mathrm{a}}$ & $2.4^{\mathrm{ab}}$ & $2.3^{\mathrm{b}}$ & $2.7^{\mathrm{A}}$ & $2.3^{\mathrm{A}}$ & 0.110 \\
\hline Energy retained as fat, $\mathrm{MJ}$ & 7.4 & 7.5 & 6.9 & $6.6^{\mathrm{B}}$ & $7.9^{\mathrm{B}}$ & 0.358 \\
\hline \multirow{2}{*}{$\frac{\text { Energy retained }}{\text { Energy intake }}, \%$} & & & & & & \\
\hline & $35.0^{\mathrm{a}}$ & $34.1^{\mathrm{ab}}$ & $31.6^{\mathrm{b}}$ & $32.5^{\mathrm{a}}$ & $35.1^{\mathrm{b}}$ & 0.668 \\
\hline
\end{tabular}

$\mathrm{a}, \mathrm{b}-\mathrm{P}<0.05 ; \mathrm{A}, \mathrm{B}-\mathrm{P}<0.01$

The gilts produced $1 \mathrm{~kg}$ more protein and $3.1 \mathrm{~kg}$ less fat than the barrows.

The weight of the liver and kidneys of pigs fed rations containing rape seeds was significantly greater than of the pigs given only RSM but this effect was not proportional to the seed content (Table 6). The addition of raw seeds to the diets in amounts of 10 or $20 \%$, increased the weight of the liver by 62 and $86 \%$, respectively, and of the kidneys by $17 \%$ in both groups $(\mathrm{P}<0.01)$.

The weight of the thyroid gland in pigs fed diets containing rape seeds was greater than in pigs that did not receive seeds, and was similar in both seed groups, 14.3 and $14.8 \mathrm{~g}$, respectively in groups RS-10 and RS-20. Plasma thyroxine levels in groups RS-10 and RS-20 were lower by 8 and $14 \%$, respectively, while that of triiodothyronine by 15 and $19 \%$, respectively, than in group RS-0. None of these differences was, however, significant. A highly significant negative correlation was found between the weight of the thyroid and the level of thyroid hormones, $r=-0.88\left(\mathrm{~T}_{3}\right)$ and $\mathrm{r}=-0.99\left(\mathrm{~T}_{4}\right)$.

The amount of energy deposited daily in fat did not differ significantly among the groups (Table 7), while the amount of energy deposited in protein in groups RS-10 and RS-20, 2.3 and 2.4 MJ, respectively, was lower $(\mathrm{P}<0.05)$ than in group RS-0. Utilization of metabolizable energy worsened with increased rape seed intake and in pigs from group RS- 20 was $9 \%$ worse $(\mathrm{P}<0.05)$ than by pigs fed the RS- 0 or RS-10 diets.

\section{DISCUSSION}

Replacing 10 or $20 \%$ of barley with rape seeds increased the ME concentration by 0.6 or $1.2 \mathrm{MJ} / \mathrm{kg}$ feed due to the increase of the digestible fat from the rape seeds. On the basis of the work by Schiemann et al. (1971) on utilization of energy from various components of the diet, somewhat better performance 
should have been expected in groups RS-10 and RS- 20 than in RS- 0 , since the degree of conversion of metabolizable energy into net energy is higher for fat than carbohydrates and protein. In our experiment, energy utilization was worse in pigs fed diets containing rape seeds than in pigs fed diets without rape seeds. This result differs, therefore, from those obtained in experiments on energy utilization by growing animals depending on the type and concentration of energy in feeds that do not contain antinutrients (e.g. Gädeken et al., 1985).

Explaining the differences in energy utilization by pigs in the particular groups is rather difficult. It is not known whether greater heat production in group RS-20 than in RS- 0 was due to different maintenance requirements or the higher cost of deposition of protein or fat. Providing isoenergetic rations in the experiment did not allow to distinguish these pathways of energy expenditure using regression analysis. Our study did show, however, that lower retention of energy in the body was the result of lower protein deposition. It was calculated that a $1 \%$ rise in the proportion of rape seeds in the diet decreased daily protein deposition by $0.8 \mathrm{~g}(\mathrm{r}=-0.51)$. A negative effect of feeding raw seeds, at both 10 and $20 \%$ levels, on the retention of nitrogen was already found at $40 \mathrm{~kg}$ body weight. This effect increased as fattening progressed resulting in lower weight gains. An effect of the time factor on the rate of body weight gain in piglets fed seeds was also found by Gill and Taylor (1989).

In the reported study, the intake of glucosinolates rose along with dietary rape seeds content. This was accompanied by hypertrophy of the thyroid gland, liver and kidneys in all animals, even those in group RS-0. In spite of the lack of the control group fed on rape-free diet in this experiment, this statement can be based on previous experiments by Fandrejewski et al. (1994) carried out on pigs from the same herd, in which a high dependence between thyroid and internal organ size and glucosinolate intake of animals was found. It was calculated that the weight of the pigs in group RS-0, receiving the least GL $(2.1 \mathrm{mM} / \mathrm{d})$ was also elevated (by about $30 \%$ in comparison to animals that did not receive glucosinolates).

In pigs fed RSM together with RS, the increase in thyroid, liver and kidney weight and decrease in secretion of $T_{3}$ and $T_{4}$ were not, however, directly proportional to GL intake. In comparison with the results of our previous experiments (Chabiera et al., 1994; Fandrejewski et al., 1994) on feeding RSM to fattening pigs, a weaker goitrogenic response to an increase of the GL level in the ration was found (from 2.1 to $7.3 \mathrm{mM} / \mathrm{d}$ ). This was all the more surprising since along with the seeds, myrosinase (Bille et al., 1983a) was probably also introduced into the digestive tract of the animals. The pigs in group RS-0 did not receive this enzyme, since it is inactivated during toasting of rapeseed meal.

The greater weight of the liver and kidneys in pigs in groups RS-10 and RS-20 suggests that part of the increased heat production can be attributed to higher 
maintenance requirements. In studies by Baldwin et al. (1980), an interrelationship was found between the basal metabolic rate and the weight of internal organs. On the other hand, in earlier studies (Fandrejewski et al., 1994) on the energy metabolism in growing pigs fed feeds with high RSM contents, liver and kidney hypertrophy was also found, but no relationship was seen between the size of the organs and the level of heat production in pigs.

The results of the study suggest that the mechanism of action of antinutrients on the growing pig is different when they come from RSM and RS than when they are derived only from RSM. When both RS and RSM were fed, the negative effect of glucosinolates on the weight of the thyroid and internal organs was similar as when only RSM was fed, but only in the low range of GL content. Each combination of RSM and RS did, however, adversely affect energy metabolism from the start of fattening and, especially protein metabolism, which has not been observed when feeding RSM (Fandrejewski et al., 1994) or RS (Skomial et al., 1993) alone. This can be explained by the presence of myrosinase in RS, an enzyme that hydrolyses glucosinolates in the digestive tract, giving rise to products that are harmful to the animal. Our results are in agreement with studies carried out on rats (Bille et al., 1983b), in which the addition of myrosinase to a diet containing $1 \mathrm{mg}$ progoitrin decreased protein utilization.

On the basis of the results of this experiment, it can be stated that raw rape seeds of double low rape in combination with rapeseed meal are not proper energy supplement for growing pigs. Although the seeds raise the metabolizable energy content in the diet when they replace cereals but they lower energy utilization and the diet contains less net energy than would result from the additivity of its components. Joint feeding of RSM and RS reduces the rate of protein deposition, a factor that is decisive for feed utilization by growing pigs.

\section{REFERENCES}

Baldwin R., Smith N.E., Taylor R., Sharp M., 1980. Manipulating metabolic parameters to improve growth rate and milk secretion. J. Anim. Sci 51, 1416-1428

Bille N., Eggum B.O., Jacobsen I., Olsen O., Sørensen H., 1983a. The effects of processing on antinutritional constituents and nutritive value of double low rapeseed meal. Z. Tierphysiol. Tierernähr. Futtermittelk. 49, 148163

Bille N., Eggum B.O., Jacobsen I., Olsen O., Sørensen H., 1983b. Antinutritional and toxic effects in rats of individual glucosinolates ( myrosinases) added to a standard diet. 1. Effects on protein utilization and organ weights. Z. Tierphysiol. Tierernähr. Futtermittelk. 49, 195-210

Brouwer F., 1965. Raport of sub-committee on constans and factors. Proceeding of 3rd Symposium on Energy Metabolism. Troon. EAAP Publ. No. 11, pp. 441-443 
Buraczewska L., Schulz E., Schröder H., 1987. Ileal digestibility of amino acid in pigs fed barleys differing on protein content. Arch. Anim. Nutr., Berlin 37, 861-867

Byczyńska B., 1971. The isothiocyanates and oxazolidinethiones determination in rape seeds (in Polish). Biul. IHAR Radzików 5, 57-61

Campbell R.G., Taverner M.R.. 1986. The effects of dietary source of fat and dietary energy content on the voluntary energy intake and performance of growing pigs. Anim. Prod. 42, 327-333

Chabiera K., Fandrejewski H., Kotarbinska M., Raj S., 1994. Energy metabolism in growing-finishing pigs fed rapeseed meal. J. Anim. Feed Sci. 3, 297-303

Fandrejewski H., 1992. Energetic aspects of feed efficiency in growing gilts (in Polish). Editor: The Kielanowski Institute of Animal Physiology and Nutrition Jabłonna, pp. 1-58

Fandrejewski H., Chabiera K., Kotarbińska M., Raj S., 1994. Heat production in growing pigs fed rapeseed meal with various glucosinolate contents. J. Anim. Feed Sci. 3, 287-296

Gädeken D., Bohme H., Oslage H.J., 1985. The influence of energy concentration caused by alterations in fibre and fat content on the efficiency of ME-utilization in growing-fattening pigs. Procceding of 10th Symposium on Energy Metabolism, Virginia. EAAP Publ. No. 32, pp. 248-25!

Gill B.P., Taylor A.G., 1989. Low glucosinolatc full-fat rapesced meal in the diets of early-weaned piglets. Anim. Prod. 49, 317-321

Glapś J., Ziółkowski T., Kozik E., 1992. Efficiency of rape secd for fattening pigs (in Polish). Rocz. Nauk. Zoot., Monogr. Rozpr. 31, 246-260

Lawrence T.L.J., 1978. Effects of micronization on the digestibility of whole soya beans and rapeseeds for the growing pigs. Anim. Feed Sci. Technol. 3, 179-189

Raj S., Kotarbinska M., Malowany K.. Kazanecka M., 1990. The nutritive value of double low rapeseed oilmeal for growing pigs (in Polish). Biul. inf. Przem. Pasz. 29, 1724

Raj S., Fandrejewski H., Kotarbinska M., Chabiera K., 1993. The energy and protein value of double-low rape sceds for growing pigs. J. Anim. Feed Sci. 2, 27-34

Skomiał J., Sokół L., Sawosz E., Stróżewski J., 1993. Ground and extruded "OO" rape seed in the diet of fattening pigs. Proceeding of Rape Seed Symposium. Radzików, pp. 164-165

Schiemann R., Nehring K., Hoffman L., Jentsch W.. Chudy A., 1971. Energetische Futterbewertung und Energienormen. Dte Landv. Verlag, Berlin

Thomke S., 1984. Further experiments with RSM of Swedish low-glucosinolate type fed to growing-finishing pigs. Swedish J. Agric. Res. 14, 151-157

\section{STRESZCZENIF.}

\section{Wykorzystanie energii i bialka przez świnic żywione dawką zawierającą nasiona rzepaku i poekstrak-} cyjną śrutą rzepakową

Dwadzieścia cztery świnie rasy polskiej zwisłouchej (po 12 loszek i wieprzków), podzielone na 3 grupy, karmiono dietami zawierającymi $18 \%$ poekstrakcyjnej śruty rzepakowej (RSM) i nasiona rzcpaku (RS) w ilości: 0 (grupa RS-0), 10 (grupa RS-10) lub 20\% (grupa RS-20) od 30 do 95 kg masy ciala. Świnie żywiono indywidualnie, skarmiając dawki o wyrównanym poziomie energii, białka i lizyny. Przy masie ciała 40,60 i $80 \mathrm{~kg}$ oznaczono strawność $\mathrm{j}$ bilans azotu. Wykorzystanie energii metabolicznej i bialka oznaczono metodą bilansu rzeźnego. Po uboju oznaczono masę tarczycy, wątroby i nerek oraz poziom hormonów $\mathrm{T}_{3} \mathrm{i}_{4} \mathrm{~T}_{4} \mathrm{w}$ osoczu krwi. 
Retencja azotu była średnio o 12 i $17 \%$ niższa $(\mathrm{P}<0.01)$ w grupie RS-10 i RS-20 niż w grupie RS-0, przy czym negatywny wpływ nasion na wykorzystanie azotu pogłębiał się wraz z postępem tuczu. Wykorzystanie energii metabolicznej u świń otrzymujących $20 \%$ RS było gorsze o 2,5 i 3,4\% $(\mathrm{P}<0.05)$ niż w grupie RS-10 i RS-0.

Wraz ze wzrostem pobrania glukozynolanów zwiększała się masa narządów wewnętrznych oraz obniżał się poziom hormonów $\mathrm{T}_{3} \mathrm{i}_{4} \mathrm{~W}$ osoczu krwi. Zmiany te jednak nie były proporcjonalne do ilości pobranych glukozynolanów.

Łączne stosowanie RSM i RS w żywieniu rosnących świń pogorszyło wykorzystanie białka i energii. 